\title{
Community Sustainability and Tourism in the Pooled Towns Route, Oaxaca, Mexico
}

\author{
Jesús Gómez-Velázquez, Rosa María Velázquez-Sánchez, Abel Antonio Morales Santiago, and \\ Armando Pérez Delgadillo
}

\begin{abstract}
Sustainability was defined as "the fact which meets the present needs without compromising the ability of future generations to satisfy their own needs." There are a lot of tourist attractions with an incredible potential but without the promotion or development needed to be streamlined, such is the case of The Pooled Towns, a set of communities in the mountains in northern highlands of Oaxaca, Mexico. This research is aimed to analyze the characteristics of the tourism project mentioned and its relation with local development and community sustainability analysis from the Commonality perspective. The development dimensions and elements systematized in the available literature were analyzed and it will have an analytical scope and empirical knowledge generation. The relevance lies in the knowledge of the involvement of the people in developing alternative tourism and its impact on community sustainability.
\end{abstract}

Index Terms - Community sustainability, ecotourism, pooled, commonality.

\section{INTRODUCTION}

According to The Ministry of Tourism in Mexico [1], 650 destinations represent ecotourism projects in Mexico and they are a growing supply. For the Indigenous Peoples Development Commission [2], 106 locations that offering ecotourism are located in indigenous communities and are distributed in 29 of the 32 Mexican states. The development of ecotourism destinations is generating income for the community and establishes the conservation of the natural environment and culture [2]. In the working paper "Tourism in Mexico" by Ministry of Tourism in Mexico [3], estimates that tourism represents 21.5 million tourists per year and according to the National Institute of Statistics and Geography and Informatics in Mexico [4] the contribution to national Gross Domestic Product (GDP), for activities related to tourism was 3.7 points in the 2nd Half of 2012.Therefore in tourism activity, heritage preservation is necessary so that future generations may know and enjoy them.

Sustainability concept established in 1983 by the World Commission on Environment and Development, was defined as "the fact which meets the present needs without compromising the ability of future generations to satisfy their own needs" [5], There is a unique geography with unique natural and cultural attractions, and preserving the features of the Zapotec culture, observed in language, worldview and

Manuscript received December 12, 2014; revised May 12, 2015.

The authors are with Universidad Autónoma Benito Juarez de Oaxaca, CO 68120 Mexico (e-mail: agame_velasquez@hotmail.com, romavesa205@yahoo.com.mx, armando.perezd@yahoo.com.mx). customary practices applied to tourism practice. The tourism takes place in the axes of alternative tourism (adventure tourism, ecotourism and rural tourism).

The problem is the status of ecotourism in indigenous communities of the region of the northern highlands of the Mexican state of Oaxaca. Ecotourism situation is among tourism development and community sustainability. Most ecotourism projects are located inserts in indigenous communities, which are characterized by beautiful natural landscapes and unique cultural elements. However, there is a contradiction between development and communality, so was raised as research question: What are the commonality aspects that integrate tourism services and as expressed in terms of development of alternative tourism in the Pooled Towns Route of North Highlands, Oaxaca, Mexico?

In the available studies on alternative tourism, there is published by [6] of the International Ecotourism Society, which mentioned the potential of alternative tourism offers in the conservation of natural areas and poverty alleviation for local communities, however, the results did not allow to observe changes in the aforementioned communities. In the study by Mexico [7], through the SWOT analysis of ecotourism and adventure tourism, determined ecotourism as an activity with potential for the development of communities that have natural areas and share cultural activities. Regard Velázquez-Sánchez and Solana [8], based on Martínez Luna [9], analyzed aspects of sustainability in indigenous communities and identified four categories with corresponding indicators.

This research is organized as follows. Available results on the study of alternative tourism in Mexico, the analysis of concept and the indicators used are presented in the section of literature review to certify alternative tourism services. The sample characteristics, variables operational definition, the procedure followed to design and application of interviews and analysis of the data were included in the Methodology section. In the results section, there are tables used to facilitate data presentation and summary explanation. The findings allow us to compare the results with the stated objective and show the relevance of this study for the understanding of the factors as elements of commonality in the development of alternative tourism projects in the region of northern highlands of Oaxaca, México.

\section{LITERATURE REVIEW}

IUCN (The World Environment Union) [10] defines ecotourism as "environmentally responsible form of tourism that consists in traveling or visiting relatively undisturbed 
natural areas, in order to enjoy, appreciate and study the natural attractions (landscape, flora and wildlife) in these areas, as well as any cultural event (present and past) that could be found there, through a process that promotes conservation, that has low environmental and cultural impact and provides for active involvement and social-economic benefit for local populations" [11]. For the Ministry of Tourism in Mexico [3], ecotourism is an alternative to conventional tourism. It is a type of tourism that is distinguished by its commitment to the contemplation of natural environment and share the culture of the host communities. As seen in the two definitions, there is a contradiction because while IUCN [10] stands tourism activity as environmentally responsible [1] includes the culture of the communities where are located the natural attractions.

Luna [9] mentions that development and community are two diametrically opposite concepts, however, indigenous communities have learned to integrate aspects of development to their culture, Martinez Luna mentioned and defined it as adaptation and that it is a form of resistance to preserve their culture the culture and adapt for development. Regard Diaz [12] coined the concept of commonality as a way to demonstrate the sustainability of indigenous communities.

The commonality has to do with the worldview; they conceive the relationship with nature as integral to man and not as an alien element and available to be used. Ecotourism as development way involves changes in community's forms, primarily related to its worldview and gradually their cultural manifestations, but provides infrastructure and resources needed to maintain and mediate with the resulting changes. To analyze in a profound way alternative tourism, we would have to take into account that mentions Coca-Pérez [13], "The analysis of community must be made considering its historical determination, its evolution in the specific territorial context and their current situation" in order to understand their worldview. According to the concept of Daltabuit-Godás-Valdivieso and Valenzuela [14], alternative tourism is "an option proposed for achieving sustainable development with the direct involvement of organized rural community" to rational and properly advantage of the natural and cultural heritage.

With regard to local development, the Mexican Association of Sciences for Regional Development [15] conceptualized it as "natural economic, cultural and social situation that welfares the people" and it coins merely in the life quality. So far there are no empirical studies on ecotourism study from the perspective of communities and even less with commonality criteria proposed by Diaz [12], categorized by Martinez Luna [9] and systematized by Velázquez and Solana [8], which have been used to analyze projects that look for development.

\section{MethodOlOGY}

In this study based on phenomenology, based on the texts of Martinez Luna [9] and [16], the characteristics that define the sustainability of communities were reviewed and an in-depth interview was designed for one resident of each community which integrates The Pooled Towns Route, defined as key informants. Another semi-structured interview directed to fifty indigenous people who lives along the communities in the same route was structured.

Variables of Commonality and elements for the development of alternative tourism were included. The study was conducted in the communities (San Miguel Amatlán, Benito Juárez, San Antonio Cuajimoloyas, Santa Martha Latuvi, San Isidro Llano Grande and La Nevería). 50 people were interviewed and 5 key informants. The obtained data have allowed making an initial identification and definition of indicators of development of alternative tourism and commonality showing the feasibility of the project in a Oaxacan community.

\section{OPERATIONAL DEFINITION OF VARIABLES}

Elements for Development of Alternative Tourism: Was defined by the attractions and sites that allows develop activities and provide services of alternative tourism and it was considered as a numerical variable. It was measured based on the attractions and sites located along the route. Commonality: It was considered as a numerical variable, based on the indicators developed by Velázquez and Solana [8] and was measured based on the answers of the interviewees.

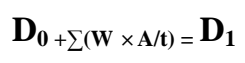

$$
\begin{aligned}
& \mathrm{D}_{0}=\text { Initial Level of Development } \\
& \mathrm{T}=\text { Variables Applied for Alternative Tourism (4) } \\
& \mathrm{W}=\text { Worldview } \\
& \mathrm{A}=\text { Adjustment } \\
& \mathrm{t}=\text { Time Variable } \\
& \mathrm{D}_{1}=\text { Resulting Level of Development }
\end{aligned}
$$

\section{PROCEDURE DESCRIPTION}

Based on the information obtained by The Ministry of Tourism in Mexico[3] and Ministry of Environment and Natural Resources in Mexico [17], was selected The Pooled Towns Route, located in Northern Highlands Region of Oaxaca, Mexico, to be analyzed under the headings of Commonality and Development of Alternative Tourism. Categories and indicators developed by Velazquez-Sanchez and Solana [8] were included. For Communality variable were included four categories and for development of alternative tourism two categories. A total of 14 indicators categorized commonality and aspects for development of alternative tourism are shown.

\section{A. Commonality}

Own Culture: Technology, Knowledge, Production, Social Norms, Culture: Medicine, Food, Creativity, Worldview. Adaptation: Originality, Values, Harmony. Own Technology: Materials, Tools, Relationship Man-Earth.

\section{B. Development of Alternative Tourism}

Attractions and Services by number variable. According to the offer of alternative tourism destinations reflected in promoting ecotourism in Oaxaca, there are 57 major 
destinations in regions of the state of Oaxaca. In Northern Highlands Region the highest number with 22 destinations are located. In the Central Valleys region there are 6 destinations reported. 5 in the Mixtecan Region. 11 in Southern Highlands. Then in the Coastal Region 13. However, few of them stand variables of Commonality in the performance of tourism project.

\section{Data Analysis}

With obtained data from the in-depth interview and based the in procedure to establish categories for alternative tourism performance in the community, explanations and reflections of key people interviewed were analyzed. With the analysis of each interview, the main elements were organized and the analysis table was built. Description of main categories was made.

About numerical data, factorial analysis was performed from the interview for fifty people in the community. The results showed three factors in the commonality variable: Own culture, Adaptation and Own Technology. In fact, the elements that distinguish and are important for community people are grouped into three categories proposed by Martínez Luna [9] for commonality variable. With the results of factorial analysis, a comparison was made with about the results found by Gómez-Velázquez [18] in nine eco- tourism projects in the coastal region of Oaxaca, México and they are summarized in Table I.

TABLE I: COMPARATIVE ANALYSIS ABOUT COMMONALITY ASPECTS THAT IDENTIFY THE PEOPLE OF INDIGENOUS COMMUNITIES WITH POTENTIAL FOR DEVELOPMENT OF ALTERNATIVE TOURISM

\begin{tabular}{|c|c|}
\hline $\begin{array}{l}\text { COMMUNITIES IN THE } \\
\text { COASTAL REGION }\end{array}$ & $\begin{array}{l}\text { ELEMENTS } \\
\text { COMMONALITY }\end{array}$ \\
\hline $\begin{array}{l}\text { La escobilla } \\
\text { Rio humedales (3) } \\
\text { Mazunte } \\
\text { Ventanilla } \\
\text { Rancho Tangolunda } \\
\text { Casa Mermejita } \\
\text { Yiimtii }\end{array}$ & $\begin{array}{l}\text { Own culture in community } \\
\text { organization. } \\
\text { Adaptation incorporating } \\
\text { infrastructure services to } \\
\text { ecotourism. } \\
\begin{array}{l}\text { Own Technology in food } \\
\text { preparation. }\end{array}\end{array}$ \\
\hline $\begin{array}{l}\text { COMMUNITIES OF THE } \\
\text { POOLED } \\
\text { ROUTE }\end{array}$ & $\begin{array}{l}\text { ELEMENTS } \\
\text { COMMONALITY }\end{array}$ \\
\hline $\begin{array}{l}\text { San Miguel Amatlán } \\
\text { Benito Juárez } \\
\text { San Antonio Cuajimoloyas } \\
\text { Santa Martha Latuvi } \\
\text { San Isidro Llano Grande } \\
\text { La Nevería }\end{array}$ & $\begin{array}{l}\text { Own culture in organization } \\
\text { through local customs. } \\
\text { Adaptationincorporating } \\
\text { infrastructure services to } \\
\text { ecotourism. } \\
\text { Own Technology in food } \\
\text { preparation, traditional medicine } \\
\text { and agro food sustainability. }\end{array}$ \\
\hline
\end{tabular}

As shown in Table I, there are the results of data analysis, sustainability indicators are expressed by the population and tested the distinction made thereof, compared to the people of the Coastal Region. According to the elements for development of alternative tourism mentioned by key informants, were highlighted which was related to natural attractions they have and services already handled. However, they don't have seen for development of new services. The study showed that the destinies of The Pooled Towns Route has enough activities for visitors interested in adventure and extreme activities, as well as ecotourists, so the diagnosis shows a fullness in alternative tourism development.

\section{RESULTS}

Below are presented in Table II, the results showing identification of commonality factors in ecotourism projects included by Gomez-Velazquez [18] in the Coastal region and which are present in the Pooled Towns Route.

As noted, community sustainability indicators are still valued and important for the people, so any development project, as in the case of alternative tourism should be considered and should appreciate their relevance to success the project and to ensure participation of the native people and promote both the target and the attractions that means to the visitor to interact with the people and for the community people to participate directly in the activities and in the services for the collective benefit from the commonality perspective.

TABLE II: ANALYSIS OF COMMONALITY INDICATORS AND AVAILABLE Elements in Alternative TOURISM PERFORMANCE of THE POOLED TOWNS ROUTE OF NORTHERN HighLANDS OF OAXACA, MEXICO

\begin{tabular}{|l|l|l|}
\hline \multirow{2}{*}{ VARIABLES } & $\begin{array}{l}\text { CATEGORIES/ } \\
\text { ELEMENTS }\end{array}$ & INDICATORS \\
\hline \multirow{3}{*}{ Commonality } & Own Culture & $\begin{array}{l}\text { Techniques Applied to } \\
\text { Management, Knowledge, } \\
\text { Production, Social Norms. }\end{array}$ \\
\cline { 2 - 3 } & Adaptation & $\begin{array}{l}\text { Originality, } \\
\text { Harmony }\end{array}$ \\
\cline { 2 - 3 } & Culture & $\begin{array}{l}\text { Medicine, Food, Creativity, } \\
\text { Worldview }\end{array}$ \\
\cline { 2 - 3 } $\begin{array}{l}\text { Development } \\
\text { of Alternative } \\
\text { Tourism }\end{array}$ & Attractions & $\begin{array}{l}\text { Materials, Tools, } \\
\text { Relationship Man-Earth }\end{array}$ \\
\hline & $\begin{array}{l}\text { Routes for walking, cycling } \\
\text { and horseback riding. } \\
\text { Rivers, lakes and springs. } \\
\text { Forest and Mountain. } \\
\text { Watching wildlife. }\end{array}$ \\
\hline
\end{tabular}

Table II shows definition of main variables: Commonality and Development of Alternative Tourism by categories or elements. This categories/elements was developed according to Martinez Luna [9] characteristics of Commonality concept. After this, based on the study on phenomenology, the indicators was found and operated according to the previous categories. The indicators provides an index of the most relevant points to integrate this ecotourism practice and explain how tourism activity is developed in indigenous communities where Commonality worldview rules.

In data analysis, Own Culture factors are distinguished by community organization form and collaboration, as well as the elements and Own Technology used in preparation of traditional foods and use of local materials for infrastructure of food and lodging.

While both factors Commonality and Adaptation of the Own Technology to recreational activities, mainly in the use of resources from community. Own Culture factors in the organization and participation of community residents in the project activities.

\section{CONCLUSIONS}

In results reviewing of The Pooled Towns Route in Northern Highlands of Oaxaca, Mexico, it is concluded that if 
there are the basic characteristics on alternative tourism development by the activities already mentioned by the key informants and because of the interest in share with visitors the natural environment in coexistence with the local people, as mentioned Ceballos-Lascuráin [11]. Potential development of alternative tourism is observed as shown in the above results by CESTUR-ITAM [7]. It is possible to achieve communication and collaboration with other nearby communities to maximize the tourist route reach, for example, the integration of key communities with natural, cultural and even historical attractions, such as the case of "Guelatao de Juarez" matching with the area of Northern Highlands, with differing results as presented by Coca - Pérez [13].

One can observe the presence of people in the community. Highlights include the interest in the project and the preservation of their language and traditions [12]. The organization highlights to be a destination of alternative tourism and adaptation to development. Therefore, the commonality may be observed. With inclusion of alternative tourism a boost is seen by external factor with harmony between the community elements. Working with foreign people to enhance the destination and set actions for conservation, achieving adaptation to developing tourism in this case.

Development of alternative tourism is a source of employment for community people. It can promote commonality within direct community involvement. The Pooled Towns Route are tourist destinations with indigenous origins and is promoted as a destination for visiting natural places, cultural interaction and recreational activities.

The obtained results in this research allow answering the research question. The inclusion of commonality elements in the services they offer in their destinations in the performance of alternative tourism in The Pooled Towns Route in Northern Highlands Region of Oaxaca, Mexico may allow adaptation for development in communities.

\section{REFERENCES}

[1] Ecotourism Attractive in Mexico, IEEE Trans. Ministry of Tourism in Mexico, pp. 1874-1968, January 2013.

[2] Ecotourism Destinations Catalogue, Commission for development of indigenous communities in Mexico, IEEE Trans. CDI México.

[3] Tourism in Mexico. (January 2013). Situation \& perspectives. IEEE Trans. Secretaría de Turismo de México. [Online]. Available: http://www.sectur.gob.mx

[4] National Statistics System. (2014). National Institute for Statistics, Geography and Informatics in Mexico. Instituto Nacional de Estadística, Geografía e Informática, México. IEEE Trans. [Online]. Available: http://www3.inegi.org.mx/

[5] G. H. Brundtland, "Our common future, world," Commission on Environment and Development, Norway, 1983.

[6] Definición y Principios del Ecoturismo, The international ecotourism society IEEE Trans. (TIES).

[7] Report on evaluation of ecotourism and adventure tourism in Mexico, vol. 4, issue 9, México, 2010.

[8] R. M. Velázquez-Sanchez and O. R. S. Vasquez, "The sustainability of indigenous communities in Oaxaca and microfinance services,' presented at $2^{\text {nd }}$ International Conference on Research, Sustainable Development and Cultural Environment of Economic Administrative Area, Faculty of Accounting and Administration, Benito Juárez Autonomous University of Oaxaca, Mexico, 2013.

[9] L. J. Martínez, "Commonality and development. Popular and indigenous culture," IEEE Trans. Government of Oaxaca State, 2003.

[10] The World Environment Union (IUCN). Chapter II: Tourism and the environment. [Online].

Available: https://portals.iucn.org/library/efiles/html/Tourism/section5.html
[11] C. Ceballos and O. Lascuraín, "Conservation and environmental impact of services in tourism-oriented sites," The Global Union for Nature, issue 85, 1993.

[12] F. D. Gomez, "One hundred questions to understand commonality," CONACULTA (Consejo Nacional para la Cultura y las Artes), National Autonomous University of México, pp. 5-12, 2004.

[13] P. Coca and B. Ruíz, "Community tourism in ecuador," Tourism Mystery in Ecuador, pp. 15-18, Quito, Ecuador, 2007.

[14] D.-G. Valenzuela-Valdiviezo, "Expectatives for ecoturism. Oportunities y challenges," Valencia University, Valencia, Spain, 2010.

[15] (1993). Development, concepts \& definition. IEEE Trans. the Mexican Association of Sciences for Regional Development (AMECIDER). [Online]. Available: http://www.amecider.org.mx/

[16] S. Robles-Hernández and R. C. J. F. Díaz, National Autonomous University of Mexico, Mexico City, Mexico, 2009.

[17] Call for certification of ecotourism destinations, IEEE Trans. SEMARNAT, February 2013.

[18] J. Gómez-Velázquez, "Ecotourism on Oaxaca's coastal region. Between development and commonality," Memories Extensive of Global Conference on Business and Finance, San José, Costa Rica, 2013.

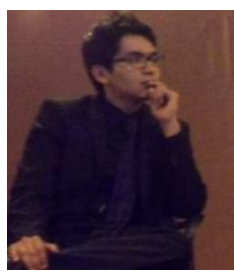

Jesus Gomez Velazquez is a member of IACSIT. He is a student of $3^{\text {rd }}$ grade of tourism \& sustainable development major in Universidad Autonoma Benito Juarez de Oaxaca. He is a student and a researcher in tourism, sustainability, community development and recently in environmental issues applied to tourism. $\mathrm{He}$ is a full time student in Universidad Autonoma Benito Juarez de Oaxaca, Mexico. He has done internships in Washington DC area in 2014 with the Emerald Planet and Management Systems International.

Mr. Jesus Gomez Velazquez's current and previous research interests are water management, regional development, environmental quality, tourism business development.

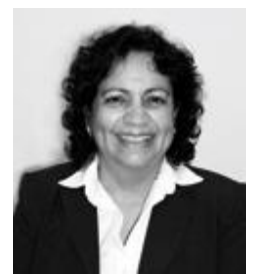

Rosa Maria Velazquez Sanchez is a member of IACSIT. Her enterprises administration graduate by Instituto Tecnológico de Oaxaca, México in 1984. She got the master in forest planning by Instituto Tecnológico Agropecuario de Oaxaca, Méxicoin 1995 and the doctorate in enterprises planning and regional development by Instituto Tecnológico de Oaxaca, México in 2000.

She is also a full time research professor at Universidad Autónoma Benito Juárez of Oaxaca, Mexico. She is actually planning to pursue the department chief in the Faculty of Business \& Accounting of the same university. She is a member of the National System of Researchers of Mexico-CONACYT and the Mexican Association of Science in Regional Development.

Professor Rosa Maria Velazquez Sanchez's current research line is tourism and sustainable development and previously she worked with micro finances and business development.

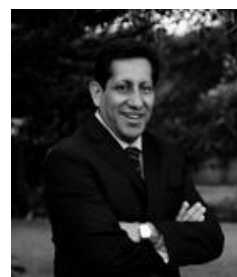

Abel Antonio Morales Santiago is a member of IACSIT. He got the B.A in public accounting by Universidad Autonoma Benito Juarez de Oaxaca, Mexico and the master in fiscal laws by Universidad Autonoma del Estado de Puebla and the PhD in fiscal sciences by Instituto de Especializacion para Ejecutivos.

Professor Abel Antonio Morales Santiago has worked in the Faculty of Accounting and Administration of Universidad Autonoma Benito Juarez de Oaxaca. He is currently the principal of this faculty and he is working in the research group. He is a member of the National College of Accountants in Mexico.

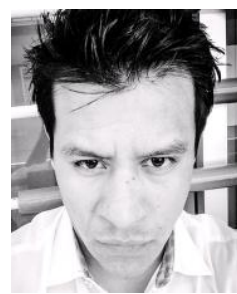

Armando Pérez Delgadillo got his B.A. in economics, UNAM in 2005, and the M.A. in economics, CIDE A.C. in 2008, and the $\mathrm{PhD}$ in applied economics, UNAM in 2011. His major research interests are experimental economics applied to environmental issues.

Mr. Armando Pérez Delgadillo now is a research professor in Economics School from Universidad Autónoma "Benito Juárez" de Oaxaca. Oaxaca, México; and a researcher associate in WWF (world wildlife fund for Nature) 